it burst into flame; very soon the mass melted and rose to an intense, white heat, the air streaming in through the spiral greatly favouring the combustion, a full spectrum of the utmost purity and splendour was formed, which continued as long as the white heat lasted, but afterwards declined from, and rapidly at, the violet end through the whole spectrum to the red, which persisted longest. On repeating the experiments, and raising a very narrow slit to the spectroscope, I found, as I anticipated, the sodium line reversed, and I had before me a miniature sun, a glowing centre emitting light of every wave-length, while the melted sodium, flowing through the intervals between the wires of the lower part of the cone and being dissipated by the heat, surrounded the liquid centre with an atmosphere absorbing light of its own refrangibility.

Thinking some of your readers would like to repeat so simple and inexpensive an experiment, I have ventured to send you this.

St. Mary Church, Torquay

T. $F$.

\section{A Wind-direction Rain-gauge}

IN your issue for yesterday, March 30 , at page 433 , you give a paragraph respecting a "Wind-direction Rain-gauge." Might I be allowed to observe that a gauge on the same principle has been in use at this place for many years, "it is arranged for four vessels" only, showing N. to E., E. to S., S. to W., and W. to $\mathrm{N}$. WM. LYalt

Literary and Philosophical Society, Newcastle-upon-Tyne

\section{Entomological Queries}

$\mathrm{CAN}_{\mathrm{AN}}$ any of your entomological readers refer me to any works or memoirs on British Ants published since the appearance of Westwood's "Classification of Insects," and not quoted by Mr. Smith in his volume on "Formicidæ" in the British Museum Catalogue? What is the scientific name of the Texas agricultural ant and of the smaller ant which it ejects from its colonies? And where can I find M. Lespes' paper or papers on the "Domestic Econnmy of Formicaries," especially with regard"to the Clavigers and other blind beetles? A. EMMET

Feb. 2I

\section{Rain produced by Fires}

IN your No. of Feb. I6, there is a letter from Mr. Laughton on the Artificial Production of Rains, which is worthy of notice from a strictly scientific point of view. I have little doubt that rains have been in comparatively rare cases caused by large fires. We may dismiss from our minds the idea that rains can be produced, even when the conditions are favourable, by all the powder that is burnt during a battle on land or sea. It is said that "in a problem of this nature, negative examples have more weight than positive." But it is surely more philosophical to hold that the one class of instances is as valuable as the other. If rains have sometimes been produced by fires, it is as well to try to eliminate the conditions under which they occur as in those cases in which they do not occur.

It is curious enough that much of the popular belief as well as a dishelief in the connection between rains and fires must be ascribed to the late Prof. Espy. After laying down with scientific accuracy the atmospheric conditions for such an occurrence, he somewhat lost sight of the principles in his instructions to the farmers of the United States for burning their felled timber for the production of rain. I need not enter into these. The negative cases are found to be numerous enough. Great fires rage over the Prairies and througti the woods in America for weeks during the antumn, and the air becomes darkened by a veil of smoke, while no clouds are to be seen. This usually occurs when the wind is from the west and the air dry, and naturally blue and bright till obscured by smoke. In such instances the theory of fires producing rains justly enough becomes tunpopular.

On the other hand Espy laid down with great precision the conditions under which rains will result from great fires in "a high dew-point and a calm atmosphere." In short, the air must be pretty well saturated with moisture, and verging upon that unstable state of equilibrium under which cumulus clouds are formed. As Espy has shown, and every observer of the phenomena will confirm, the gorgeous cumulus clouds of summer are not seen when the air is much disturbed by winds.
Their very formation and existence depend upon ascending currents. Previous to Espy's investigations, it was supposed that the formation of cumulus was due to the expansion of the vapour of water by the heat of the sun and its consequent diffusion upwards through the permanent gases till it was condensed above. He clearly showed by experiment that vapour has little power of permeating air under the ordinary pressure of the atmosphere. And he drew the inference that it could be only carried into the higher strata by ascending currents. This, I think, is amply borne out in the formation of all clouds.

Fires then, are only likely to produce rains during comparatively calm weather. In the positive instances given by Espy, most of the observers state that the air was calm and sultry. One of the staff of the United States surveyors when in Florida mentions, that by fuing the bush "whenever there was no wind stirring, we were sure to get a shower." Great fires are cor. paratively rare in this country, and I have never scen the formation even of cloud here rom such a cause. However, I did once observe this phenomenon. Many years ago when sailing up the Mississippi near its mouth, in a clear and cool evening, after the subsiding of a "Norther," a great fire was burning among the reeds on its west bank. Above the dark smoke the true cumulus cloud was distinctly formed. Its bright and rounded form was beautifully brought out in the setting sun. No other clouds were visible around, and these were soon left behind as we ascended the river.

If we reflect on the matter it is difficult to conceive how clouds could be formed by means of fires during windy weather. The ascending columns could not be formed under such conditions, for the heated air would be rapidly swept off, and diluted with the mass of air rushing past. This may be illustrated by other examples better known than the formation of the cumulus. Volcanoes are well known to produce at times clouds as well as rains. But all the vapour or heat that Vesuvius could emit during an active eruption would not produce rains when a strong and dry north-west wind was blowing across its top. So also the beautiful and true cumulus cloud that so often bovers over the Falls of Niagara is only seen in calm weather. Under favourable atmospheric conditions $I$ have lately been informed by Dr. Henry Washington that the Niagara cloud sometimes gives rise to rains and electrical phenomena. The true inference seems to be that great fires will not produce rain, excepting "the air is calm, and the dew-point high." ROBERT RUSSELL

Pilmuir, Leven, Fifeshire,

\section{A BILL TO ESTABEISH THE METRIC SYSTEM OF WETGHTS AND MEASURES}

THE following Bill, prepared and brought in by Mr. J. B. Smith, Sir Charles Adderley, Sir Thomas Bazley, Mr. Graves, Mr. Baines, Mr. Albert Pell, Mr. Muntz, and Mr. Dalglish, has been ordered to be printed by the House of Commons :- -

Whereas it is desirable that the weights and measures of the United Kingdom should be decimalised, and made to correspond with those of other countries.

And whereas the use of metric weights and measures is now legal, but no provision has been made for procuring the standards of said metric weights and measures, and for verifying and stamping those in use under the said $\mathrm{Act}$.

Be it enacted by the Queen's most excellent Majesty, by and with the advice and consent of the Lords Spiritual and Temporal, and Commons in this present Parliament assembled, and by the authority of the same as follows :-

I. From and after the expiration of ( ) years after the passing of this Act, the length of the metre to be prepared under the authority of the Privy Council for Trade, verified by comparison with the original standard in Paris, having the words and figures "Standard Metre, 1871," engraved upon it, and kept in the custody of the Warden of the Standards, shall be and is hereby declared to be the unit or only standard measure of lineal extension, wherefrom or whereby all other measures of extension whatsoever, whether the same be lineal, superficial or of capacity, shall be derived, computed, and ascertained, and all such measures shall be taken in decimal multiples or decimal parts of their respective units.

2. The unit of the measure of surface shall be the square of ten metres, which shall be and is hereby denominated the "are." 